\title{
Inland excess water mapping using hyperspectral imagery
}

\author{
Bálint Csendes ${ }^{\mathrm{A}^{*}}$, László Mucsi ${ }^{\mathrm{A}}$ \\ Received: May 17, 2016 | Revised: July 21, 2016 | Accepted: October 12, 2016
}

\begin{abstract}
Hyperspectral imaging combined with the potentials of airborne scanning is a powerful tool to monitor environmental processes. The aim of this research was to use high resolution remotely sensed data to map the spatial extent of inland excess water patches in a Hungarian study area that is known for its oil and gas production facilities. Periodic floodings show high spatial and temporal variability, nevertheless, former studies have proven that the affected soil surfaces can be accurately identified. Besides separability measurements, we performed spectral angle classification, which gave a result of $85 \%$ overall accuracy and we also compared the generated land cover map with LIDAR elevation data.
\end{abstract}

Keywords: inland excess water, SAM classification, spectral separability, LIDAR, hyperspectral remote sensing.

\section{Introduction}

Inland excess water analysis is a popular research topic among Hungarian geographers and ecologists, even the approaches of its scientific definitions show a great variety (Pálfai, 2001).

The phenomenon is usually considered as an environmental problem for its economic consequences and for the severe losses it causes in agriculture (Szatmári, van Leeuwen, 2013). Inland water not only reduces crop production but may also act as a medium of contaminations (Mucsi, 2001).

Oil contamination and leakage can be well observed using remote sensing both in terrestrial and marine environments (Hese, Schmullius, 2009; Leifer, et al., 2012), however, the selection of spectral signatures might be complicated and constrained by data quality (Brekke, Solberg, 2005; Hese, Schmullius, 2009). Since the most distinctive spectral pattern of contamination is the significant decrease in reflectance values in the near-infrared range (Hese, Schmullius, 2009), and the same feature is attributed to areas exposed to increased soil moisture, map- ping inland excess water surfaces has its special importance. The research of Tits et al. 2013 pointed out that the classification of dry soils shows a higher absolute but lower relative error compared to that of wet soils, mainly due to the difference in the intensity of reflectance.

It is also predictable that the future risk of flooding will probably increase due to climate factors (Bartholy, et al., 2007).

Recent studies have shown that inland excess water can also be accurately detected in medium-resolution satellite images using artificial neural network (ANN) approaches or spectral unmixing (van Leeuwen, et al., 2012; van Leeuwen et al. 2013). The main categories of classifications based on unmixing were the endmembers of soil, vegetation and water surfaces (Csendes, 2011; Mucsi, Henits, 2011). There are promising examples of accurate hyperspectral analysis of soil moisture content and inland excess water (Dely, et al., 2010; Sobrino, et al., 2012).

The aim of this research was to present an accurate classification on hyperspectral imagery and to find

\footnotetext{
A Department of Physical Geography and Geoinformatics, Faculty of Science and Informatics, University of Szeged, Egyetem utca 2-6, 6722 Szeged, Hungary; bcsendes@geo.u-szeged.hu

* Corresponding author: Bálint Csendes, e-mail: bcsendes@geo.u-szeged.hu
} 
statistical approaches for discriminating inland excess water map classes based on spectral and elevation data.

\section{Study area}

The aerial photography was recorded at the outskirts of Szeged, Hungary, over the flood-plain of the river Tisza (Figure 1). The so called Tápai-rét micro region is located north of the confluence of the rivers Tisza and Maros and is known for its periodic floodings occurring in the lower parts of the area. In 2010 the Car-

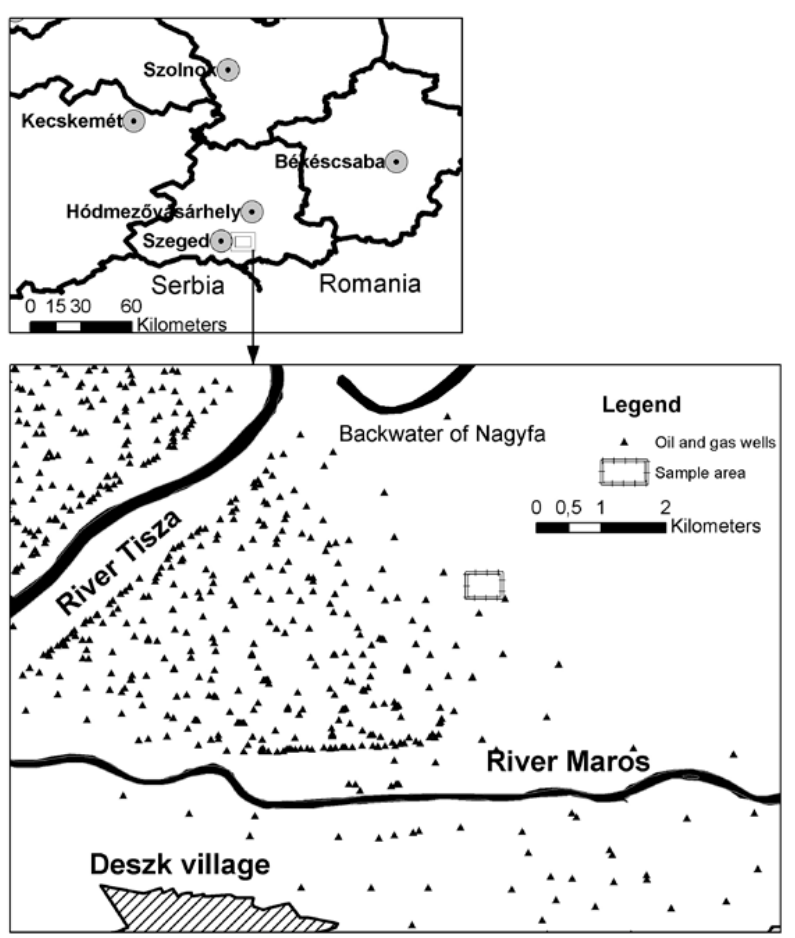

Figure 1. Location of the study area in southeastern Hungary

pathian Basin received an extremely high amount of precipitation and, as a consequence, a large proportion of the Great Hungarian Plain was flooded by inland excess water (Figure 2).

Inland excess water might be a consequence of inappropriate water management, besides a few envi- ronmental factors, e.g. specific soil properties and climatic patterns the lack of maintenance of the irrigation canals can also lead to the formation of significant water patches and thus impede agricultural activities. As the study area is situated on a flood plain in the proximity of the confluence of the rivers Tisza and Maros and the soil bed consists mainly of smallgrained deposits, it is particularly vulnerable to floods.

\section{Data}

The hyperspectral data was collected using an AISA sensor from airborne platform in September, 2010. The spatial resolution of the data is 1.5 meters and the spectral resolution varies between 4.9 and 6.28 nanometers depending on the wavelength. Over the study area, the hyperspectral image covers a footprint of approximately 110 thousand square meters.

In November 2009 LIDAR elevation data was recorded over the western parts of the sample area with an Optech ALTM 3100 laser scanner. The output map of the survey has an average point density of 1.4 per $\mathrm{m}^{2}$ (Szatmári, et al., 2012), hence this information can be used for predicting the possible locations of depressions and inland water surfaces.

\section{Methods}

Image classifications were performed using Spectral Angle Mapping (SAM), which is a widely used method that has the capability of comparing spectral angles regardless of illumination. In other words, the length of the spectral vector is irrelevant.

For the examination of our training areas we used a spectral separability measure called Transformed Divergence, which is an improved version of the Divergence approach, and a useful tool for predicting the performance of classifications (Swain, Davis, 1978). Index values have their range between o and 2, where o refers to complete overlapping and 2 means perfect separability.

Ground truth data was collected on a series of field surveys, where wet surfaces were identified and re-

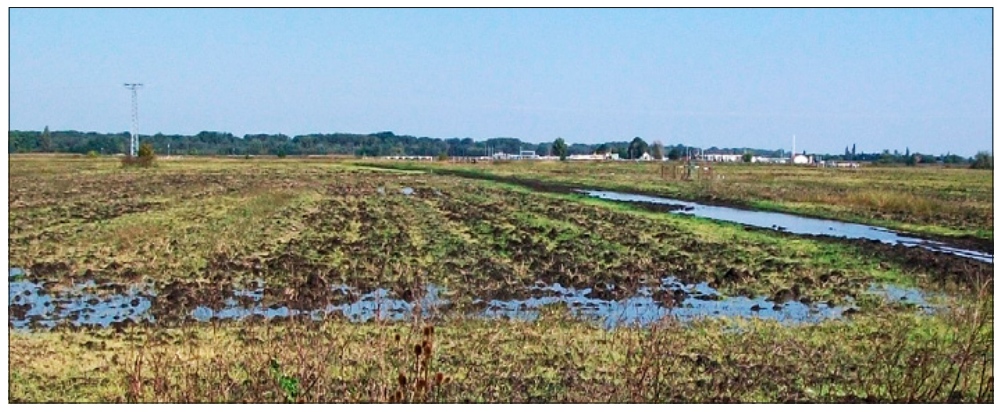

Figure 2. Inland excess water surface in the Tápai-rét study area (Photography: Zalán Tobak, 20 September 2010) 
corded in dry periods and also during flooding. Training sites for the supervised classification were selected using both the database of the field survey and the true colour visualization of the hyperspectral imagery.

Hyperspectral image analysis was performed in ENVI/IDL environment, including the evaluation of the classification results and the visualisation of reflectance curves.

\section{Results}

\section{Hyperspectral analysis}

After some substantial ground measurements we defined training sites for wet and dry soils, vegetation and water surfaces. Although the boundary between these categories might be fuzzy, we aimed to select pure pixels that lack spectral admixture. Spectral signatures of the four land cover types are presented in Figure 3 . The reflectance curve of the vegetation class shows the general spectral characteristics attributed to plants, first of all the red edge, while the three categories of inland excess water mapping including the soil surfaces covered by water share the same fashion of spectrum having the intensity of reflectance as the main pattern of distinction.

In order to assess the correctness of the training site selection, we performed spectral separability measurements on the sample pixels. According to the separability values, the smallest separability can be found between the sites of dry soil, while vegetation is almost perfectly separable from the rest of the classes (Table 1). A higher level of overlapping (1.716) takes place between wet soil and water surfaces, probably due to the shallow water bodies that show optical properties similar to soils because of their sediment content.

Following the removal of noisy spectral bands we performed a spectral angle classification (SAM) on hyperspectral data. Our goal was to avoid unclassified pixels and to find the closest spectral class for every part of the image, hence we did not define any limits for the spectral angle in this process. The classification has an overall accuracy of $85 \%$ on the testing sites and a kappa coefficient of 0.8 .

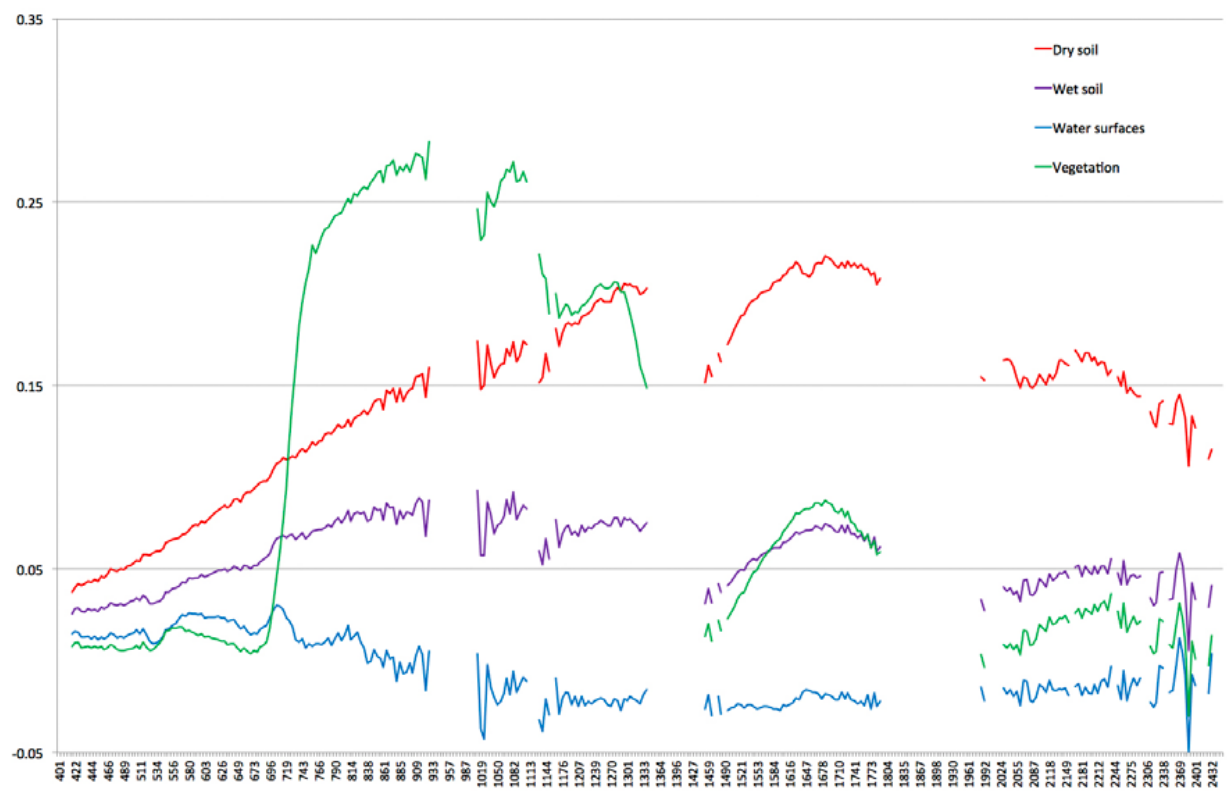

Figure 3. Reflectance curves of the main land cover types: vegetation (green line), dry soil (red), wet soil (purple), and water surfaces (blue)

Table 1. Separability values of mapping categories

\begin{tabular}{|l|c|c|c|c|}
\hline $\begin{array}{l}\text { Transformed } \\
\text { Divergence }\end{array}$ & Water surfaces & Wet soil & Dry soil & Vegetation \\
\hline Vegetation & 2 & 1.999 & 1.879 & 0 \\
\hline Dry soil & 1.98 & 1.273 & 0 & \\
\hline Wet soil & 1.716 & 0 & & \\
\hline Water surfaces & 0 & & & \\
\hline
\end{tabular}




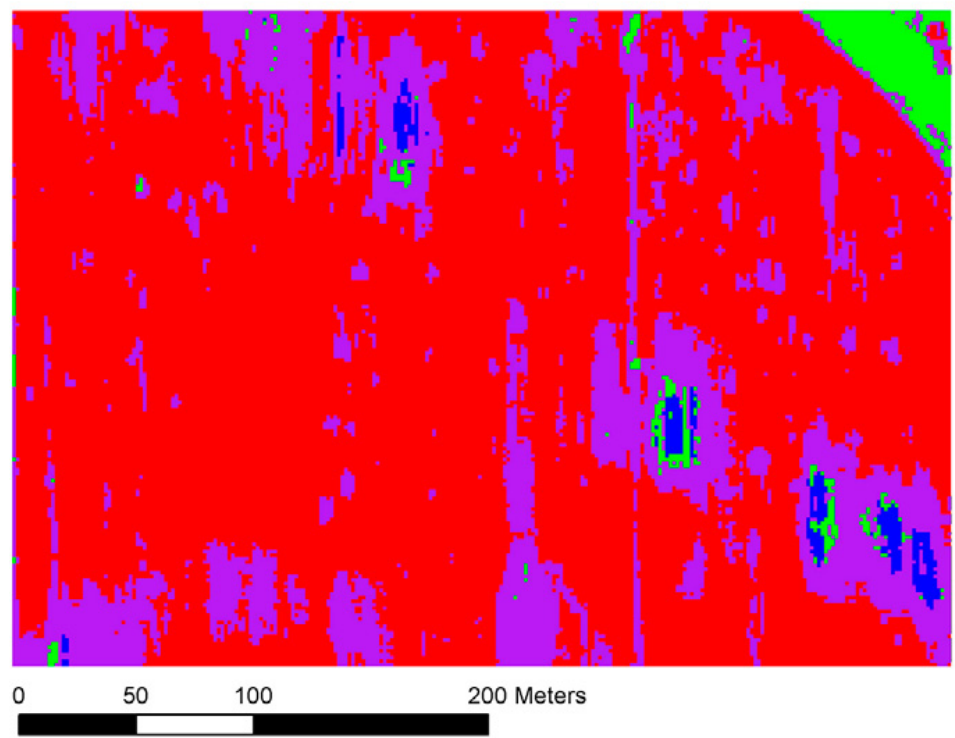

Figure 4. SAM classified map of the study area (red area - dry soil, purple - wet soil, blue - water surfaces, green - vegetation)

The map of the SAM analysis shows the spatial patterns of inland excess water (Figure 4). 74.2 percent of the pixels was classified as dry soil, $22.3 \%$ of them as wet soil, while only $3.5 \%$ was identified as water surface or vegetation, where the latter category is also related to inundation on our study area. The chequered area in the upper right corner of the image indicates vegetation adjacent to a drainage canal.

\section{LIDAR analysis}

LIDAR data covers $20.71 \mathrm{~km}^{2}$ of the floodplain, where elevation values range from 73.04 to 95.62 meters a. s. 1. The map partially overlaps with the footprint of the hyperspectral aerial photography providing the possi- bility to analyse correspondence between microrelief and soil moisture.

The average elevation of the oil and gas wells in the Tápai-rét area is at 77.36 meters a. s. 1., slightly lower than that of the entire micro region, which is 77.42 meters. Concerning both the distribution of the elevation values (Figure 5.) and the high number of wells under 77 meters, the comparison with the inland excess water statistics (Table 2) implies that many of these facilities are exposed to the risk of flooding.

The hyperspectral image is overlapped by the LIDAR elevation model at its western edge on a stripe of 65 meters in width and 280 meters in length. This part of the study area is characterized by inland ex-

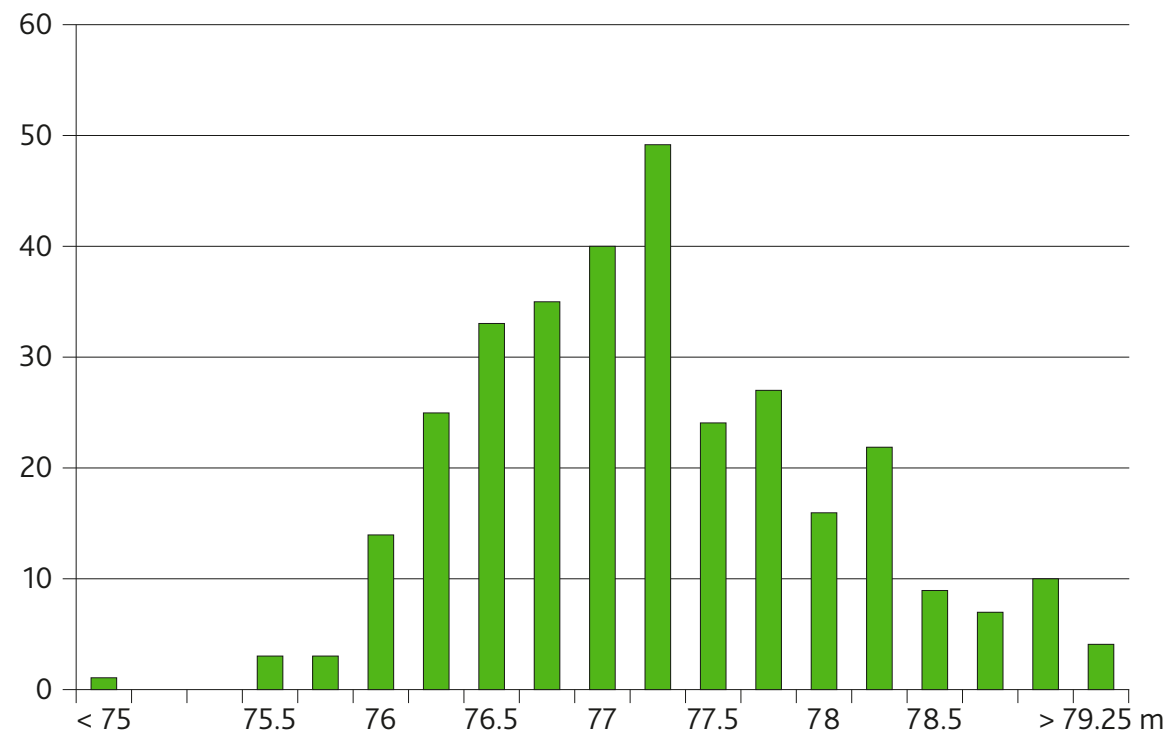

Figure 5. Elevation distribution of oil and gas wells (meters a. s. l.) 
Table 2. Elevation statistics on the four land cover classes of SAM analysis

\begin{tabular}{|l|c|c|c|c|c|}
\hline & $\begin{array}{c}\text { Entire classified } \\
\text { area (7770 pixels) }\end{array}$ & $\begin{array}{c}\text { Water surfaces } \\
\text { (13 pixels) }\end{array}$ & $\begin{array}{c}\text { Wet soil } \\
\text { (1550 pixels) }\end{array}$ & $\begin{array}{c}\text { Dry soil } \\
\text { (6162 pixels) }\end{array}$ & $\begin{array}{c}\text { Vegetation } \\
\text { (45 pixels) }\end{array}$ \\
\hline Min & 76.88 & 76.9 & 76.88 & 76.94 & 76.91 \\
\hline Max & 77.78 & 76.95 & 77.75 & 77.78 & 77.72 \\
\hline Mean & 77.412 & 76.922 & 77.24 & 77.457 & 77.343 \\
\hline St. dev. & 0.208 & 0.015 & 0.252 & 0.167 & 0.342 \\
\hline
\end{tabular}

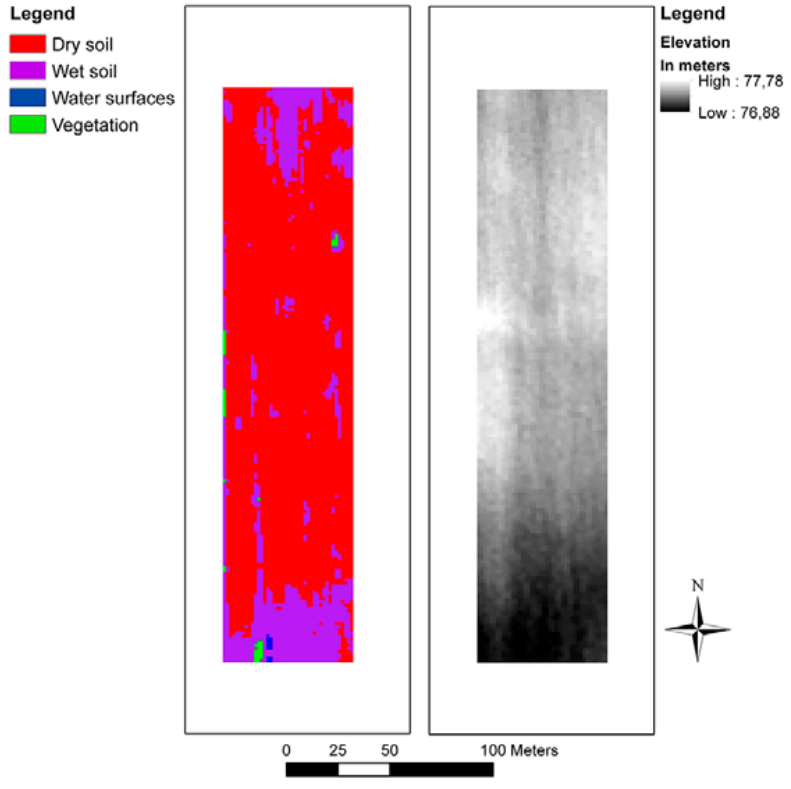

Figure 6. Comparison of SAM classification results with LIDAR elevation data

cess water patches situated in a north-south direction, fitting the shape of the lower surfaces (Figure 6). On the right side of Figure 6, the LIDAR model is presented, where brighter pixels indicate higher elevation. When comparing the two maps it is recognizable - as expected - that wet soils and water surfaces occupy the relatively lower parts of the territory and also the deep trenches, while the heights are usually associated with dry soils.

On the overlapping area of the classified image and the LIDAR model we performed some basic statistical calculations regarding the altitudinal characteristics of certain classes. Water surfaces are located at the lowest parts of the sample area with all the pixels under the level of 77 meters (Table 2). Dry soils also show relatively small standard deviation (0.167) having a mean elevation slightly above the average of the entire area. The intermediate category of wet soils has a much higher variance, however, the mean value is significantly smaller than the overall average level of 77.412 meters, designating the location of high water content at the lower surfaces. Pixels classified as vegetation cannot be explicitly associated with any of the elevation ranges.

\section{Conclusions}

Ground data collection is a crucial part of inland excess water mapping since the boundary of the main land cover types (dry soil, wet soil, and water surfaces) often looks fuzzy as presented by the spectral separability scores. However, it was proven that spectral angle classification can provide an accurate result on hyperspectral imagery for an estimation of the spatial extent of periodic floodings.

The motivation for this study comes from the ecological vulnerability of the micro region caused by the presence of various oil production facilities. According to the results the combination of LIDAR elevation data and high resolution hyperspectral imagery can further improve the reliable identification of potential natural hazard.

\section{Acknowledgements}

This research was supported by the European Union and the State of Hungary, co-financed by the European Social Fund in the framework of TÁMOP 4.2.4. A/2-111-2012-0001 'National Excellence Program'.

\section{References}

Bartholy, J., Pongrácz, R., Gelybó, Gy. 2007. Regional climate change expected in Hungary for 20712100. Applied ecology and environmental research 5(1), 1-17.

Brekke, C., Solberg, A.H.S. 2005. Review: oil spill detection by satellite remote sensing. Remote Sensing of Environment 95, 1-13.

Csendes, B. 2011. Belvíztérképezés szubpixel-alapú osztályozással,Landsat 7 ETM+ mőholdfelvételek alapján (In English: Mapping of inland excess water using sub-pixel classification on Landsat 7 ETM+ satellite images). First prize winner of the XXX. National Scientific Students' Association's Conference on Earth Sciences, Physics and Mathematics in Nyíregyháza, 27-29 April 2011. 46 pp.

Dely, F., Westsik, V., Bencsik, Gy. 2010. Belvíz képződési és belvíz információs rendszer fejlesztése (In English: Development of an information system on inland waters and their formation). Geodézia és Kartográfia 9, 25-29. 
Hese, S., Schmullius, C. 2009. High spatial resolution image object classification for terrestrial oil spill contamination mapping in West Siberia. International Journal of Applied Earth Observation and Geoinformation 11(2), 130-141.

Leifer, I., Lehr, W. J., Simecek-Beatty, D., Bradley, E., Clark, R., Dennison, P., Hu, Y., Matheson, S., Jones, C. E., Holt, B., Reif, M., Roberts, D. A., Svejkovsky, J., Swayze, G., Wozencraft, J. 2012. State of the art satellite and airborne marine oil spill remote sensing: application to the BP Deepwater Horizon oil spill. Remote Sensing of Environment 124, 185-209.

Mucsi, L. 2001. Characterisation of oil-industrial contamination using aerial and thermal images. In: Buchroithner, M. (ed.) Proceedings of the 2oth EARSel symposium Dresden: A Decade of TransEuropean Remote Sensing Cooperation, Balkema, Rotterdam, 373-377.

Mucsi, L., Henits, L. 2011. Belvízelöntési térképek készítése közepes felbontású ürfelvételek szubpixel alapú osztályozásával (In English: Generating inland excess water maps using subpixel classification of medium resolution satellite images). Földrajzi Közlemények 135 (4) 365-378.

Pálfai, I. 2001. A belvíz definíciói (In English: Definitions of inland excess water). Vizügyi közlemények 83(3), 376-392.

Sobrino, J. A., Franch, B., Mattar, C., Jimenez-Munoz, J. C., Corbari, C. 2012. A method to estimate soil moisture from Airborne Hyperspectral Scanner (AHS) and ASTER data: Application to SEN2FLEX and SEN3EXP campaigns. Remote Sensing of Environment $117,415-428$.

Swain, P.H., Davis, S.M. (eds.) 1978. Remote Sensing: The Quantitative Approach, N.Y., McGraw-Hill.

Szatmári, J., Szíjj, N., Mucsi, L., Tobak, Z., van Leeuwen, B., Lévai, Cs., Dolleschall, J. 2012. Comparing LIDAR DTM with DEM-5 of Hungary. In: Geiger, J., Pál-Molnár, E., Malvić, T. (eds.): New horizons in Central European geomathematics, geostatistics and geoinformatics: Selected studies of the 2011 Croatian-Hungarian Geomathematical Convent, Mórahalom, 151-158.

Szatmári, J., van Leeuwen, B. 2013. Inland excess water - Belvíz - Suvišne unutrašnje vode. Szeged - Novi Sad, ISBN 978-963-306-263-O

Tits, L., Somers, B., Stuckens, J., Farifteh, J., Coppin, P. 2013. Integration of in situ measured soil status and remotely sensed hyperspectral data to improve plant production system monitoring: Concept, perspectives and limitations. Remote Sensing of Environment 128 197-211.

van Leeuwen, B., Mezősi, G., Tobak, Z., Szatmári, J., Barta, K. 2012. Identification of inland excess water floodings using an Artificial Neural Network. Carpathian Journal of Earth and Environmental Sciences $7(4), 173-180$

van Leeuwen, B., Henits, L., Mészáros, M., Tobak, Z., Szatmári, J., Pavic, D., Savic, S., Dolinaj, D. 2013. Classification methods for inland excess water modeling. Journal of Environmental Geography 6(12), 1-8. 